УДК $550.837+551.247 .1+551.435 .164$

\title{
ПРИМЕНЕНИЕ МЕТОДОВ ЭЛЕКТРОРАЗВЕДКИ С КОНТРОЛИРУЕМЫМИ ИСТОЧНИКАМИ ДЛЯ ВЫЯВЛЕНИЯ ПРИЧИН РАЗВИТИЯ СУФФОЗИОННО-ПРОСАДОЧНЫХ ПРОЦЕССОВ
}

\author{
Шалагинов Александр Евгеньевич ${ }^{12,}$ \\ shalaginovae@ipgg.sbras.ru
}

Неведрова Нина Николаевна, ${ }^{13}$,

nevedrovann@ipgg.sbras.ru

Шапаренко Илья Олегович',

shaparenkoio@ipgg.sbras.ru

\author{
Бабушкин Сергей Михайлович ${ }^{4}$, \\ bab@gs.sbras.ru \\ 1 Институт нефтегазовой геологии и геофизики им. А.А. Трофимука СО РАН, \\ Россия, 630090, г. Новосибирск, пр. Академика Коптюга, 3. \\ 2 Новосибирский государственный технический университет, \\ Россия, 630073, г. Новосибирск, пр. К. Маркса, 20 \\ ${ }^{3}$ Новосибирский государственный университет, \\ Россия, 630090, г. Новосибирск, ул. Пирогова, 1. \\ ${ }^{4}$ Сейсмологический филиал Федерального исследовательского центра «Единая геофизическая служба» РАН, \\ Россия, 630090, г. Новосибирск, пр. Академика Коптюга, 3.
}

\begin{abstract}
Актуальность работы обусловлена недостаточностью знаний о причинах развития суффозионных процессов, выраженных в виде провалов земной поверхности, угрожающих инфраструктуре промышленного производства в Прикаспийской впадине. Цель: определение приповерхностного и глубинного геоэлектрического строения участка проявления суффозионно-просадочных образований для выяснения возможных причин их возникновения.

Объектом исследования являются суффозионно-просадочные образования в виде воронкообразных провалов земной поверхности глубиной от 1 до 6 м в количестве 15 штук, расположенных в трёх практически параллельных зонах.

Методы. Весь объем полевых данных получен тремя разноглубинными методами геоэлектрики: электротомография, вертикальное электрическое зондирование, нестационарное электромагнитное зондирование. Обработка, интерпретация, визуализация данных осуществлялась с помощью интерактивных программных комплексов моделирования и инверсии ЭРA, EMS, Zond, Res2D, ERTLab. Обоснование результатов проведено на основе анализа и сопоставления полученных данных геоэлектрики с априорными геологическими данными.

Результаты. По результатам выполненных работ с максимальной глубинностью до 400-500 м построены разрезы и карты распределения удельного электрического сопротивления на разных глубинах, трехмерные геоэлектрические модели, как для приповерхностной, так и глубинной части участка. В результате геологической интерпретации данных выделены зоны (по параметру УЭС), к которым приурочены существующие воронки, определено направление выноса разрушенных (размытых) горных пород. Выявлены структуры, связанные с зонами развития суффозионно-просадочных процессов, и сформулированы возможные причины их формирования.

Выводы. Показана высокая эффективность комплекса электромагнитных методов, использованных на участке с деструктивными явлениями. Сделан вывод, что основной механизм образования воронок связан с вымыванием известнякового и солевого "цемента» из неоген-четвертичных отложений, с дальнейшей разгрузной в более глубокие обводненные горизонты. Этот комплекс может быть рекомендован при решении аналогичных задач в других регионах, где имеются зоны проявления суффозионных процессов, а также для мониторинга их развития.
\end{abstract}

\section{Ключевые слова:}

Геоэлектрическое строение, вертикальное электрическое зондирование, электротомография, нестационарное электромагнитное зондирование, суффозионные процессы.

\section{Введение}

Как известно, суффозия - это сложный процесс выщелачивания растворимых компонент горных пород, механического выноса мелких частиц и подземной эрозии с нарушением структуры грунтов, формированием ослабленных и разуплотненных зон и полостей и возможным образованием на земной поверхности деформаций (блюдец, воронок, впадин). Возникновение и развитие суффози- онных образований относят к одному из видов опасных геологических процессов. Здания, инженерные сооружения, коммуникации, попадающие в зону их влияния, могут испытывать значительные деформации вплоть до аварийных ситуаций и разрушений с негативными промышленными и экологическими последствиями $[1,2]$.

Развитие суффозионного процесса в физических параметрах - это аномальное разуплотнение 
и аномальное изменение электропроводности в различных по масштабу объемах горных пород. Соответственно последствия этих процессов должны проявляться в электрическом и электромагнитном поле, что позволяет обосновать использование электроразведки для картирования потенциальных деструктивных образований.

Учитывая, что развитие суффозии приводит к изменению во времени электропроводности отложений, появляется возможность оценивать последовательные стадии развития таких процессов вплоть до возможного образования деформаций в приповерхностных отложениях путем проведения повторных электроразведочных работ.

В пределах горного отвода одного из месторождений Прикаспийской впадины были обнаружены проявления опасных суффозионных процессов в виде воронкообразных провалов земной поверхности глубиной от 1 до 6 м (рис. 1, А) [3]. Всего таких образований выявлено 15. На участке исследования они расположены в трёх практически параллельных зонах, ориентированных с запада на восток (рис. 1, Б).

Так как развитие суффозионных образований может угрожать промышленной инфраструктуре месторождения, необходимо выявить возможные причины их образования на основе изучения особенностей строения участка геофизическими методами.

В ходе выполнения работ в 2017 г. с целью определения геоэлектрических параметров горного массива, подверженного суффозии, были привлечены разноглубинные методы постоянного и переменного тока: вертикальное электрическое зондирование (ВЭЗ), электротомография (ЭТ), электромагнитное зондирование становлением поля (ЗС). Для детального расчленения самой верхней части разреза используется метод ЭТ, который в настоящее время наиболее востребован для широкого спектра малоглубинных задач. Метод совмещает принципы электрического зондирования и профилирования и обладает высокой разрешающей способностью [4]. Метод ВЭЗ применяется для определения строения разреза до глубин в первые сотни метров, хорошо согласуется с данными ЭТ для приповерхностных отложений и с данными $3 \mathrm{C}$ на глубинах от 50 до 100 м [5]. Метод 3С привлечен для исследования глубинной части разреза. Для всех методов имеются современные аппаратурно-методические и программно-алгоритмические средства моделирования, инверсии, двухтрехмерной визуализации [6-8].

\section{Краткая геологическая характеристика участка исследования}

В геолого-структурном отношении участок исследования расположен во внутренней части северной бортовой зоны Прикаспийской впадины. В разрезе осадочного чехла можно выделить три структурных комплекса: подсолевой, солевой и надсолевой, которые слагают отложения палеозоя (пермская система), мезозоя (триасовая, юрская и меловая системы) и кайнозоя (неогеновая и четвертичная системы).

Горные породы пермской системы представлены в основном гипсами, ангидритами с тонкими субгоризонтальными прослоями мелкокристаллических доломитов; толщей каменной соли с прослоями доломитов, ангидритов и гипса. В верхней части залегают отложения, сложенные пачкой мергелистых и песчанистых глин.

Литологический состав триасовых отложений представлен песками, полимиктовыми песчаниками, конгломератами и глинами. Разнозернистые песчаники содержат глину, гальку кварца, кремней. Карбонатные глины с содержанием пирита имеют разнообразную пеструю окраску (краснобурые, голубовато-серые).

Отложения юрской системы в районе участка исследования сложены песчано-глинистыми породами. Преобладают пески светло-серые, серые, коричневато-серые, мелкозернистые, кварцевые, глинистые, содержащие рассеянную и в виде линз гальку кварца и кремня. Выше по разрезу пески сменяются песчано-глинистой толщей, характеризующейся переслаиванием серых и темно-серых песчанистых глин с песком и алевритом.

В меловой системе наблюдаются песчанистые глины, обладающие неясной слоистостью, а также выделяются черные жирные глины, участками сажистые. В глинах встречаются многочисленные друзы гипса, конкреции пирита и гнезда зеленовато-серого глауконитового песка. Выше по разрезу выделены слабо песчанистые, слюдистые, жирные глины. Окраска глин серая, темно-серая с зеленоватым оттенком. В глинах встречаются тонкие прослои крепких песчаников зеленовато серого цвета.

Неогеновые отложения с резким стратиграфическим несогласием залегают на различных горизонтах нижнего мела и триаса. Нижняя часть разреза представлена зеленовато-серыми, темно-серыми глинами с прослоями зеленовато-серых глауконитовых песков, песчаников с галькой и гравием меловых пород. В верхней части залегают коричневые и красновато-бурые глины, суглинки, желтовато-серые пески.

Отложения четвертичной системы образовались в континентальных условиях и представлены желто-бурыми, коричнево-бурыми, реже мелоподобными грубыми неслоистыми суглинками с редкой плохо окатанной галькой меловых отложений и хорошо окатанной мелкой галькой уральских пород.

Морфологически участок исследования представлен делювиальным склоном и речными террасами. Суффозионные воронки расположены на границе третьей надпойменной террасы и делювиального склона в тыловой закраине.

В тектоническом плане для участка работ, как и для всей прибортовой зоны Прикаспийской впадины, характерно наличие над комплексом пород 


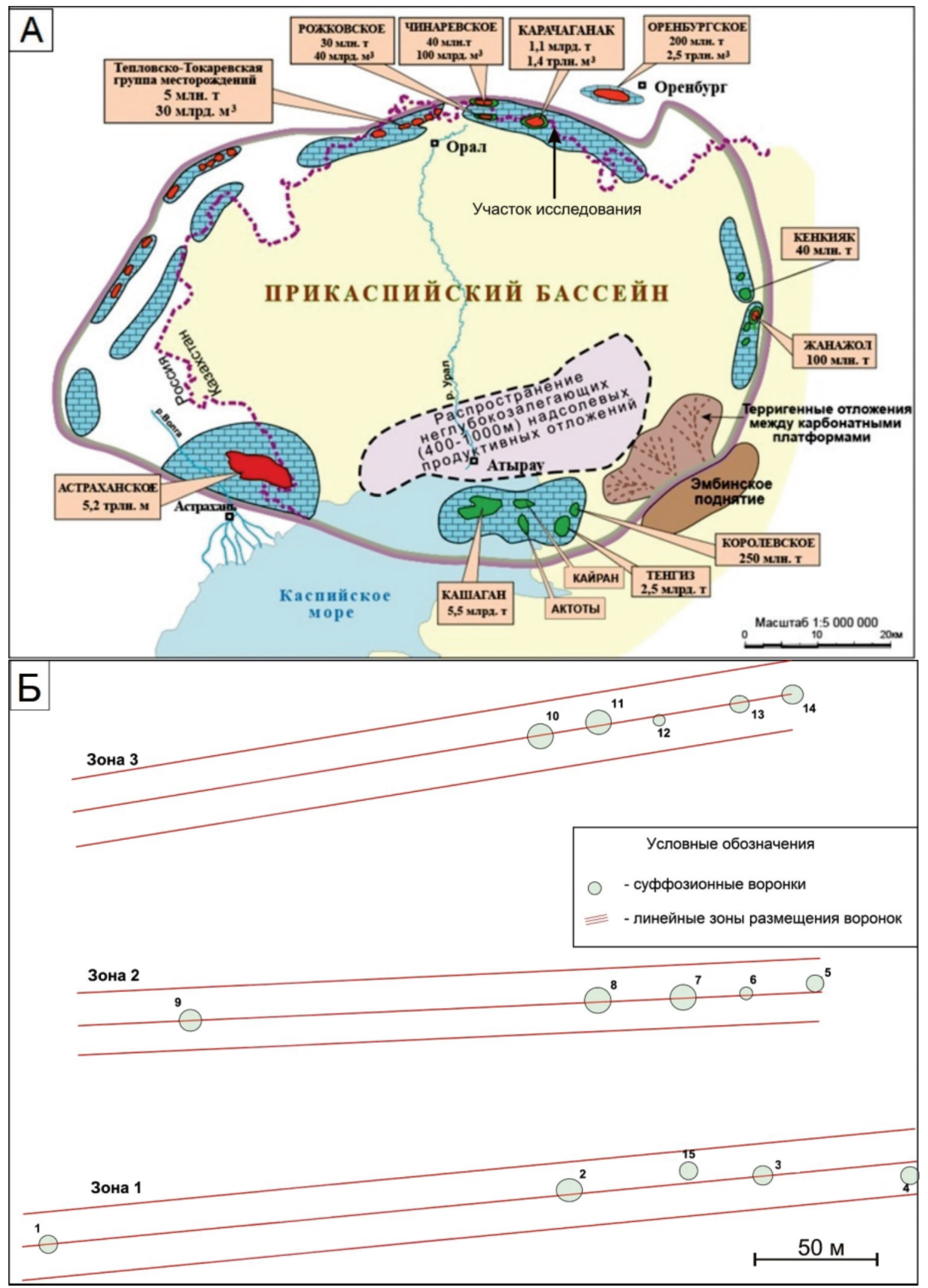

Puс.1.А) карта Прикаспийской нефтегазоносной провиниии; Б) схема расположения суффозионных воронок на участке исследования Fig. 1. A) map of the Caspian oil and gas province; B) schematic map showing the location of the suffosion funnels 
фундамента трех структурных этажей, которые неадекватно реагировали на тектоническую активизацию региона и образовали специфические, присущие только им, дислокации.

Нижний структурно-литологический комплекс палеозоя, охватывающий породы до артинского века включительно, характеризуется тектоно-седиментационными структурами рифовых массивов.

В среднем структурно-литологическом комплексе, сложенном пластичной солевой толщей кунгура, образовались резко дисгармоничные структуры по отношению как к подстилающему, так и к перекрывающему этажам. Эти структуры получили в геологической литературе название «соляные», а области их распространения - области проявления «соляной тектоники».

Верхний структурно-литологический комплекс характеризуется своеобразием структурных форм, образованных в красноцветной толще верхней перми и триаса, основным морфологическим типом которых являются синклинальные складки.

Проявившаяся уже после формирования континентальных красноцветных образований верхней перми и терригенных толщ триаса соляная тектоника полностью видоизменила подсолевой структурный план. Однако развитие солянокупольных структур было во многом предопределено структурными особенностями элементов фундамента, поскольку соляные купола и валы большей частью повторяют ориентировку бортового подсолевого уступа.

Таким образом, поскольку участок находится в области развития соляно-купольной тектоники, можно предположить, что деструктивные явления могут быть связаны с выщелачиванием растворимых солей, поступающих в почву с паводковыми водами, в верхних слоях суглинков, супесей и глин [2].

\section{Методика измерений комплекса методов геоэлектрики}

Исследования проводились с использованием современных технических средств и методик наземной электроразведки.

Электромагнитные зондирования (3С) выполнены цифровой телеметрической аппаратурой серии «БАЙКАЛ МЭРС», по методике пространственно-временной регистрации сигнала становления поля с индуктивной установкой $\mathrm{Q}, \mathrm{q}$ ( «соосные петли») [9]. В качестве генераторной конструкции $(Q)$ использовались незаземленные петли квадратной формы со стороной равной 100 и 200 м. Измерения осуществлялись незаземленной квадратной петлей (q) со стороной 50 и 100 м. На индуктивную составляющую поля практически не влияют высокоомные экраны и приповерхностные неоднородности, имеется повышенная устойчивость к промышленным и магнитотеллурическим помехам [10]. Ток в генераторной петле был выбран при проведение опытных работ на уровне $3,0-3,5 \mathrm{~A}$ для измерения начальной стадии переходного процесса и 20,0-25,0 А для его поздней стадии. Минимальная амплитуда измеряемого сигнала составила 0,2-0,5 мкВ, что позволило достигнуть глубинности исследования до 450-500 м.

Измерения методом ВЭЗ выполнены симметричной градиентной четырехэлектродной установкой Шлюмберже с максимальным разносом AB/2 - 480 м, с использованием аппаратуры SGD «MEDUSA». При проведении опытных работ было выявлено, что кривая ВЭЗ уверенно выходит на опорный геоэлектрической горизонт на глубинах 100 м, начиная с разносов АВ/2 120-150 м.

При планировании полевых работ было предложено проводить измерения методами ВЭЗ и ЗС в одних и тех же пунктах в два этапа [11]. На первом этапе пройдены два ортогональных профиля (рис. 2, А) длиной в 1200 м, пересекающие участок исследования, для определения направления выноса разрушенных (размытых) горных пород; а на втором этапе измерения выполнены по площади (рис. 2, Б) размером $360 \times 460$ м непосредственно в зоне обнаруженных воронок для выявления закономерностей развития суффозионно-просадочных процессов.

Самый большой объем полевых работ выполнен методом электротомографии (ЭТ), (многоэлектродные зондирования высокой плотности на постоянном токе) с использованием электроразведочной станции «Скала-48» для получения геоэлектрических параметров верхней части разреза [12].

Методом ЭТ проведены детальные измерения на площади проявления воронок по параллельным профилям, широтного и меридионального простирания (рис. 3). Шаг между профилями составлял 10 м. Для создания профиля необходимой длины применялась нагоняющая расстановка (roll along). 48 электродов объединены в косу общей длиной в 240 м, разделенную на два сегментами по 24 электрода с шагом 5 м между ними. После начального измерения на двух сегментах происходит перенос первого сегмента для продолжения непрерывного профиля и так несколько раз до достижения нужной длины $[13,14]$.

Таким образом, в результате полевых работ методами ВЭЗ и ЗС выполнены измерения в 38 пунктах. Методом электротомографии получены данные по 48 меридиональным профилям длиной 355 м и по 11 профилям широтного простирания длиной $475 \mathrm{M}$.

\section{Обработка и интерпретация полевых данных}

Интерпретаиия данных ЗС. Обработка и интерпретация полевых данных 3 С осуществлялась в два этапа. Вначале была выполнена предварительная обработка с помощью специализированных программных средств, результатом которой являются сами измеренные сигналы (ЭДС), очищенные от помех, и их трансформанты - кривые кажущегося удельного электрического сопротивления $\left(\rho_{\tau}\right)$, электропроводности. 


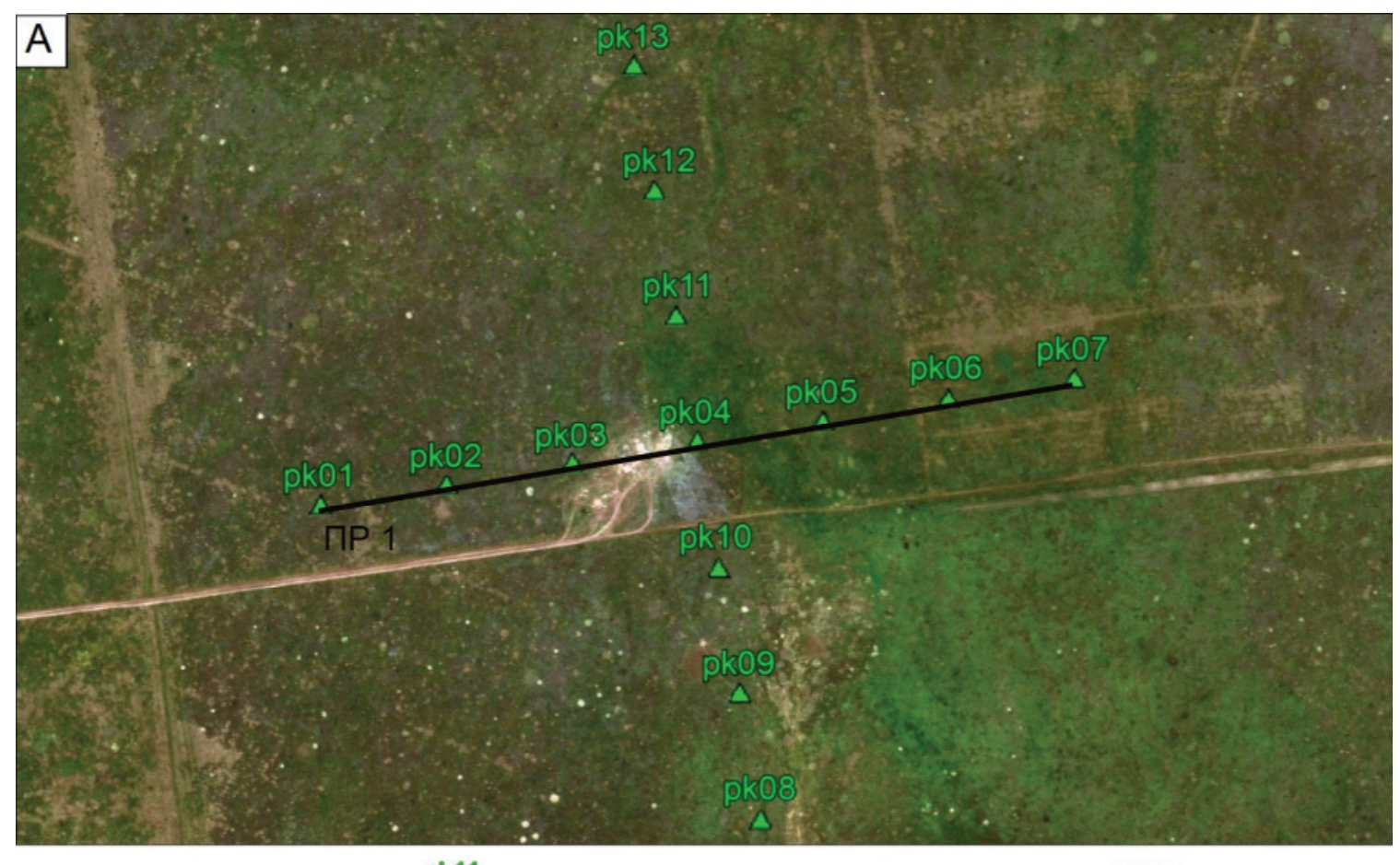

pk11 - Пункт физических наблюдений ЗС и ВЭЗ

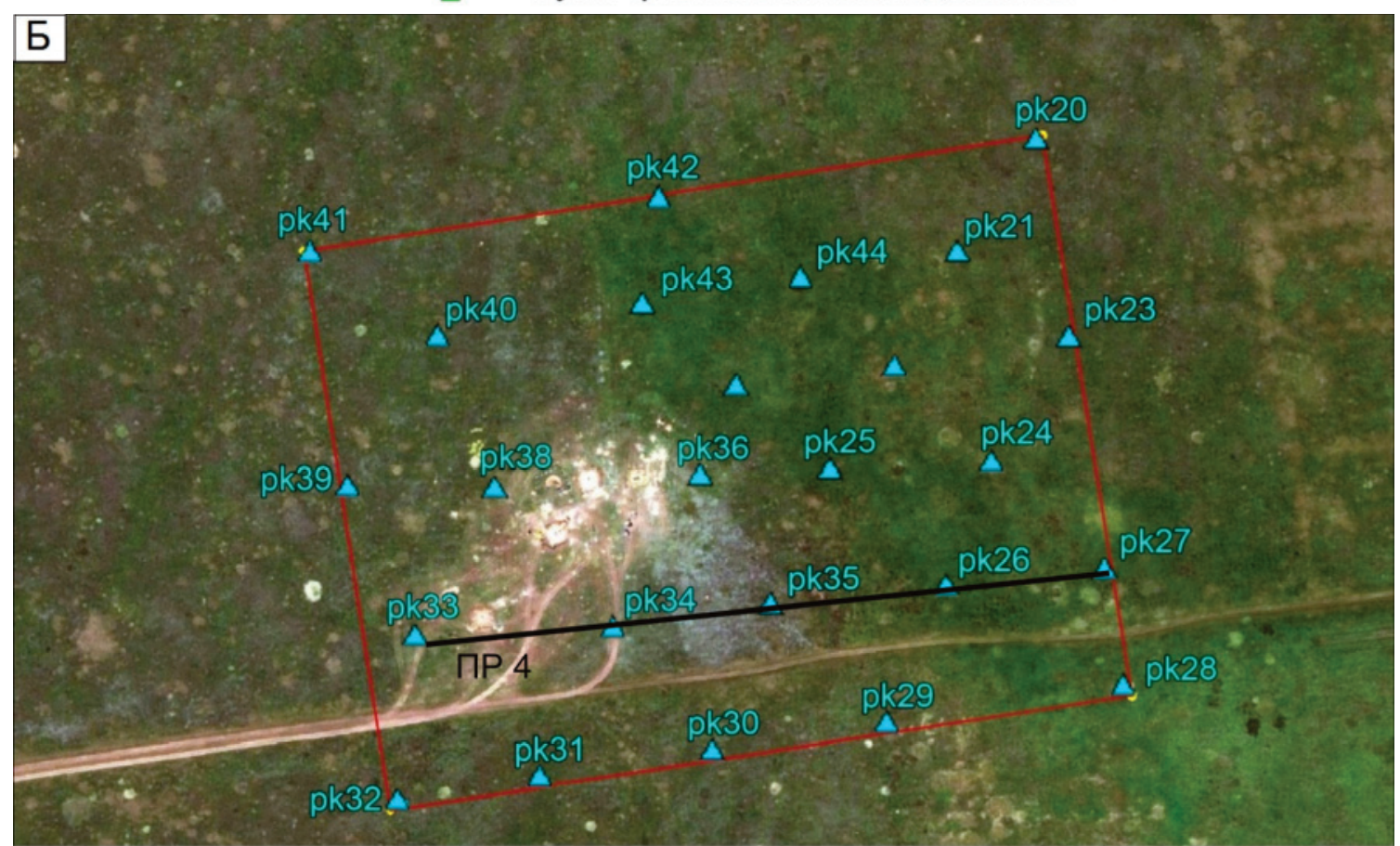

pk34 - Пункт физических наблюдений ЗС и ВЭЗ

- Граница исследуемого участка

Рис. 2. Размещение пунктов регистрации вертикального электрического зондирования (ВЭЗ) и зондирования становлением поля (ЗС): A) по ортогональным профилям; Б) на участке детальных работ

Fig. 2. Placement of registration points of vertical electric sounding (VES) and transient electromagnetic sounding (TEM): A) on orthogonal profiles; 5 ) on the site of detailed works 


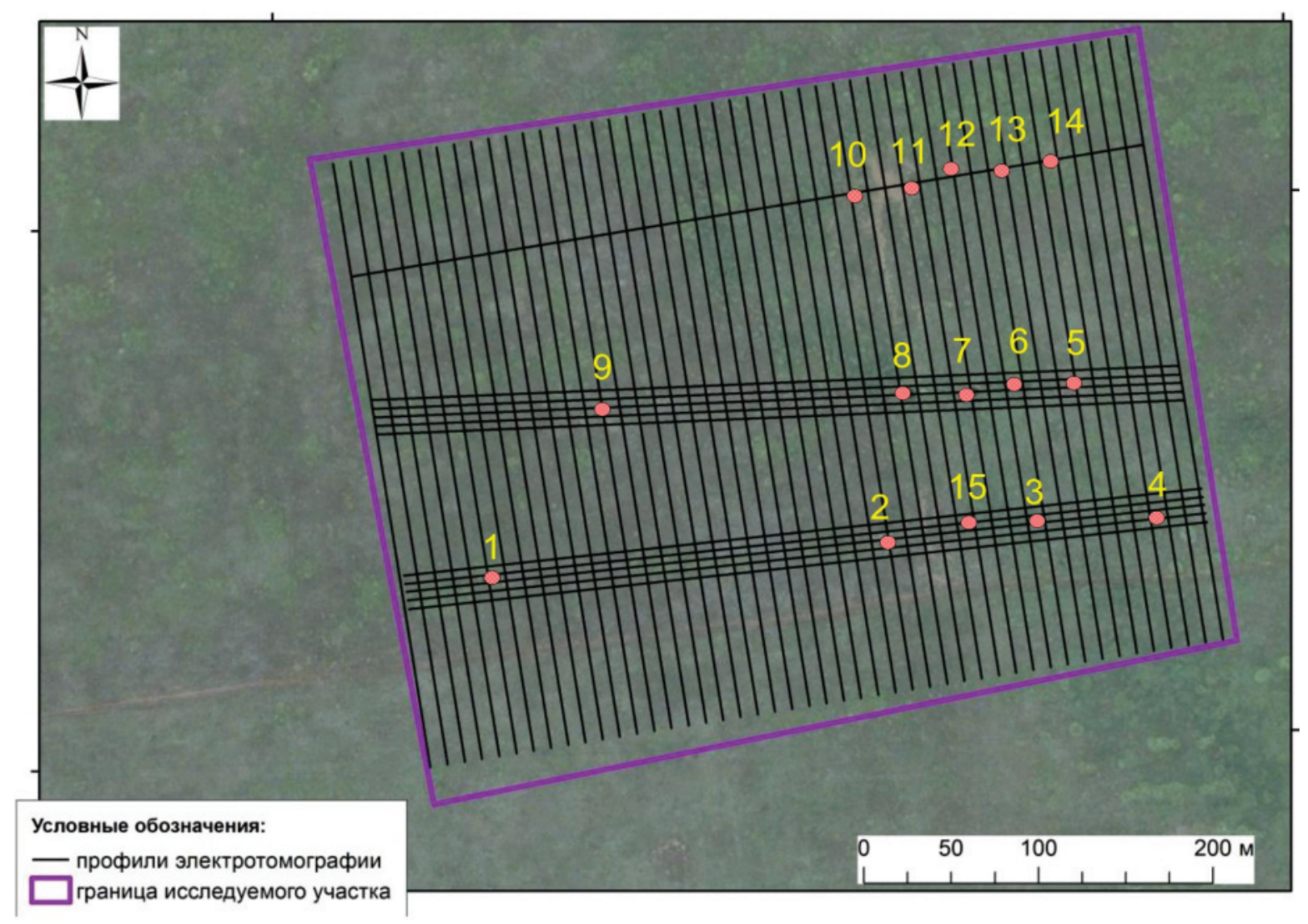

Рис. 3. Размещение профилей электротомографии на участке исследования

Fig. 3. Placement of electrotomography profiles on the studied area

Количественная интерпретация проведена на следующем этапе с использованием интерактивных программных комплексов моделирования и инверсии: Эра, EMS, разработанных в ИНГГ СО PAH [15], и ZondTEM1D на основе горизонтальнослоистой модели [16]. Каждый комплекс содержит несколько функциональных пакетов, с помощью которых можно провести численное моделирование, оценить результаты интерпретации. Для полученных геоэлектрических параметров вычисляются погрешности их определения и степень влияния на электромагнитное поле, области локальной эквивалентности, кроме того, выполняется оценка глубинности зондирования [17].

Вначале выполнена интерпретация полевых данных, полученных при измерениях по ортогональным профилям с большими размерами генераторно-приемной установки (ГП размером $200 \times 200$ м, ИП - 100×100 м). Глубинный геоэлектрический разрез по широтному профилю ПР 1 получен на основе профильной интерпретации данных $3 \mathrm{C}$ пикетов ПК 1-ПК 7 с помощью программного комплекса ZondTEM1D, в котором реализован подход, учитывающий данные в соседних точках зондирования (рис. 4). На геоэлектрическом разрезе приведен рельеф дневной поверхности по линии профиля ПР 1 с соотношением масштабов по вертикали и латерали $1: 30$, а также показано размещение суффозионных воронок, приуроченных к траектории профиля.

В ходе интерпретации данных $3 \mathrm{C}$ обоснована шестислойная модель среды с усложнением её до семислойной в пикетах ПК 1 и ПК 2 . Появление низкоомного интервала вначале профиля на глубинах 400-500 м обусловлено наличием проводящего горизонта в кровле соленосного купола.

На геоэлектрическом разрезе четко выражена тенденция погружения кровли горизонта с повышенным значением УЭС до 20-50 Ом·м (краснокоричневый цвет), представленного по геологическим данным уплотненными породами глинистой фракции триасового возраста в интервале глубин кровли от 80 м в западной части профиля до $300 \mathrm{~m}$ в его восточной части.

Согласно залегающие на нем более низкоомные горизонты с уровнем УЭС в $3,2-6,0$ Ом·м отнесены к породам меловой и юрской систем. Данные геоэлектрические горизонты сложены породами глинистых и известняковых фракций с высоким уровнем минерализации, их мощность возрастает с первых метров в районе пикета ПК 2 до 250 м и более в ПК 7.

Приповерхностные горизонты с УЭС в интервалах $6,1-12,0 \mathrm{OM} \cdot \mathrm{M}$ относятся к неоген-четвертичным $(\mathrm{N}, \mathrm{Q})$ отложениям. Мощность этих отложений в районе ПР 1 изменяется от значений $~ 80$ м в ПК 1 западной части профиля до $20-25$ м в его вос- 


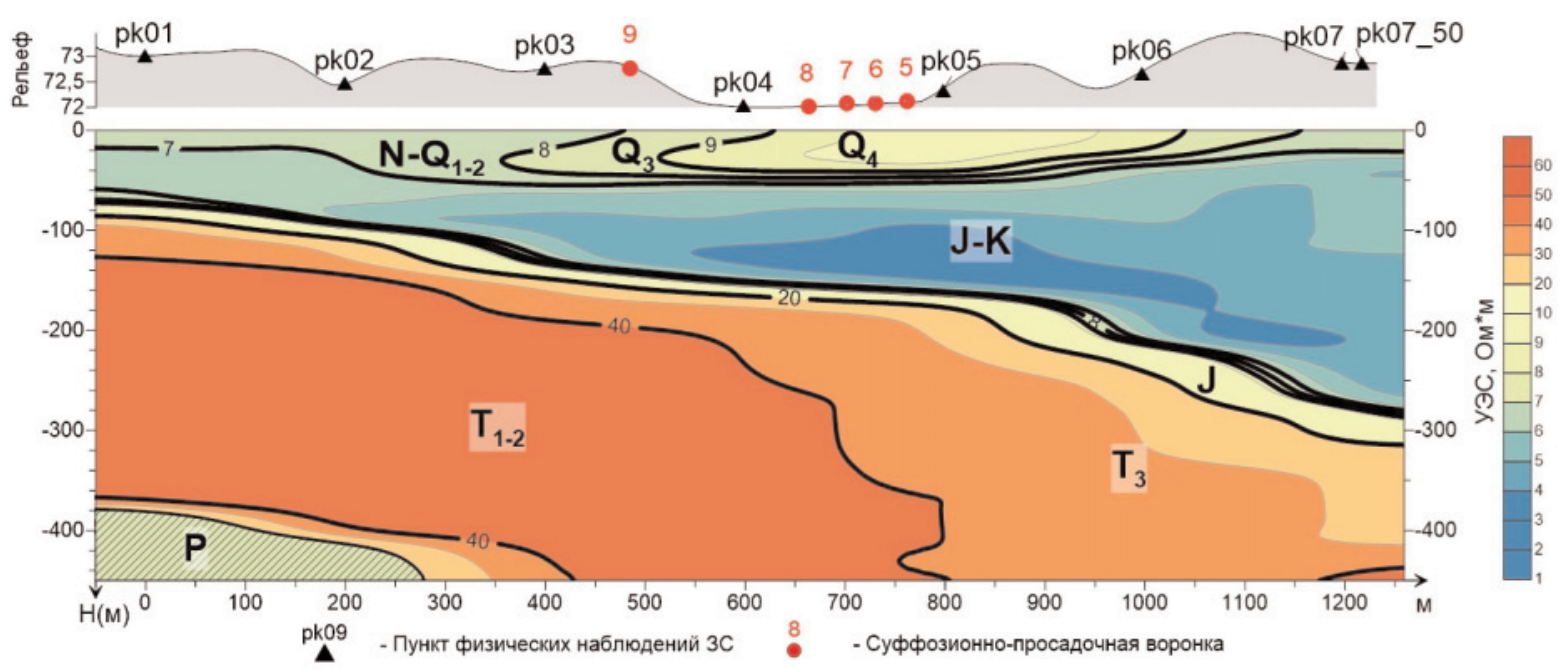

Pис. 4. Геоэлектрический разрез по профилю ПР 1 по данным зондирования становлением поля (ЗС)

Fig. 4. Geoelectric section on the PR 1 profile according transient electromagnetic sounding (TEM) data

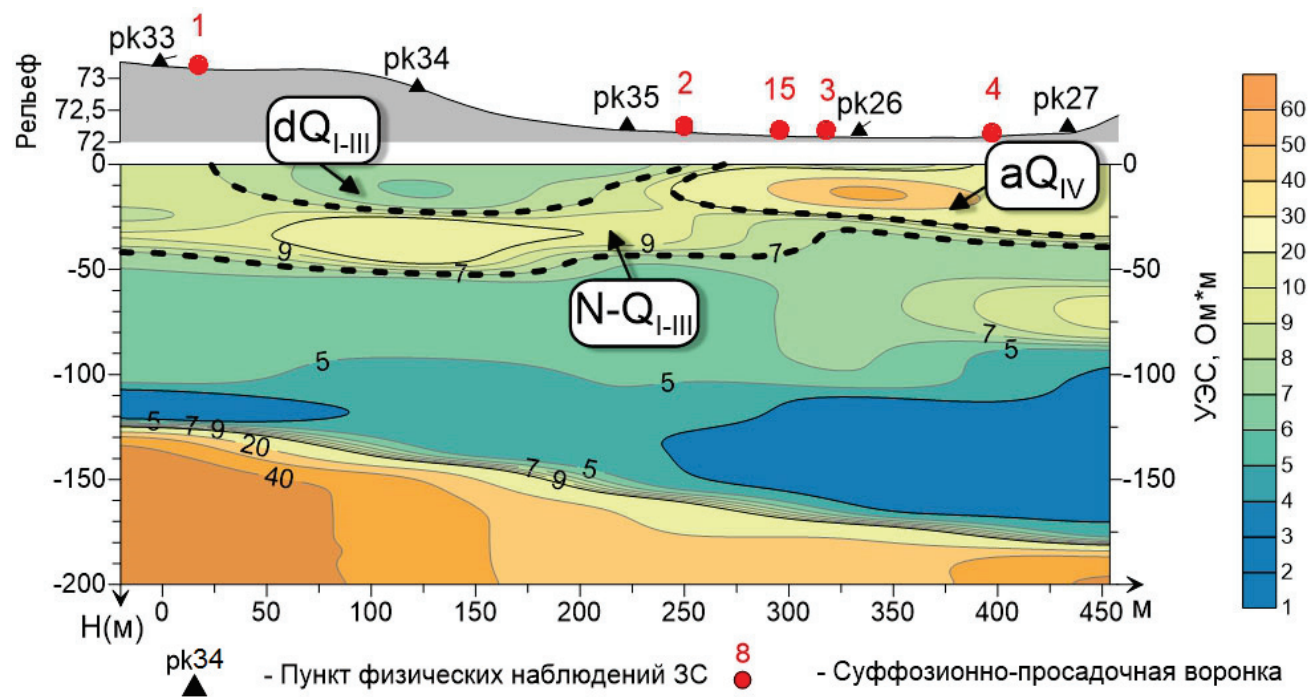

Pис. 5. Геоэлектрический разрез по профилю ПР 4 по данным зондирования становлением поля (ЗС)

Fig. 5. Geoelectric section on the PR 4 profile according transient electromagnetic sounding (TEM) data

точной части (ПК 7). Воронки 5-8 находятся на профиле между ПК 4 и ПК 5 . Значения УЭС четвертичных отложений на данном участке профиля достигает 12 Ом·м, что является аномальным для верхней части разреза.

Разрезы по ортогональным профилям ЗС (ПР 1, ПР 2) показали, что на участке детальных работ (рис. 2, Б) с развитыми суффозионно-просадочными проявлениями в виде воронок глубина до кровли пород с повышенными значениями УЭС в 20-50 Ом'м, представленных плотными глинами триаса, составляет от 130 до 180-200 м.

Для более детального расчленения верхней части разреза в зоне развития воронок по результатам опытно-методических работ была выбрана более локальная установка ЗС с меньшими размерами генераторно-приемных петель (ГП -
$100 \times 100$ м, ИП - 50×50 м). Размеры установок позволили при достаточной глубинности исследования (до опорного горизонта) повысить детальность представления верхней части разреза. На геоэлектрическом разрезе по профилю 4 (ПК $33-\Pi К ~ 27)$ линии расположения воронок совпадают с направлением погружения кровли опорного геоэлектрического горизонта, соотнесенного с глинами триаса (рис. 5). Также в этом направлении отмечается возрастание мощности низкоомных горизонтов юрской и меловой систем.

Неоген-четвертичные отложения верхней части разреза залегают с заметным несогласием на подстилающих горизонтах. При этом четко прослеживается тенденция приуроченности основной группы воронок, кроме воронок 1 и 9 , к участкам с повышением УЭС от 7-9 до 14-30 Ом·м. 
В целом по результатам интерпретации данных ЗС получено геоэлектрическое строение до глубин в $500 \mathrm{м}$, выявлено положение кровли и значения УЭС соленосного купола, определена мощность триасовых водоупорных глин ( 300 м) и их погружение на восток. По более детальным измерениям охарактеризованы подповерхностные отложения в зоне воронок.

Интерпретация данных ВЭЗ. Обработка и интерпретация полевых данных ВЭЗ также осуществлялась в два этапа. На первом этапе, непосредственно в ходе измерений, по значениям тока в источнике, разности потенциалов между приёмными электродами MN, размерам использованной установки вычислялось кажущееся удельное сопротивление $\left(\rho_{k}\right)$ для оценки качества полевых данных. На втором этапе количественной интерпретации выполнялась одномерная и двумерная инверсия, а также визуализация результатов с помощью программного комплекса «Zond» [16].

Поскольку в основу программы ZondIP1D положена концепция профильной интерпретации, данные ВЭЗ по профилю рассматриваются как отражение геологического разреза в целом, а не как набор независимых кривых зондирования, с которыми работают по отдельности. Геоэлектрический разрез по широтному профилю ПР1 построен на основе совместной интерпретации данных ВЭЗ 1-7 (рис. 6).

Глубина до кровли опорного горизонта в 75 м по данным ВЭЗ определена только в пункте 1. В последующих пунктах кровлю горизонта проследить по данным ВЭЗ не представляется возможным, поэтому она показана условно по данным интерпретации ЗС. Значения УЭС опорного горизонта достигают $~ 50$ Ом·м.

Характеристики залегающих выше низкоомных отложений со значениями удельного электрического сопротивления 4-7 Ом·м согласуются с данными $3 \mathrm{C}$ и отнесены по геологической привязке к породам меловой и юрской систем. Их мощность установлена только в районе ПК 1 в 80 м.
Приповерхностные горизонты неоген-четвертичных отложений неоднородны по значению удельного электрического сопротивления, которое изменяется по латерали от 5-8 до 15-20 0м·м. Их мощность минимальна в пункте 1 , где составляет $4 \mathrm{~m}$, и достигает $40 \mathrm{~m}$ в центре профиля. В районе пунктов ПК 2-4 до глубин примерно в 20 м в этих отложениях выделяется протяженный низкоомный горизонт со значениями УЭС 3-5 Ом·м. К более высокоомным неоген-четвертичным отложениям с УЭС в 18-20 Ом·м, развитым до глубин в 50-60 м в районе ПК 4, 5, приурочена зона образования воронок 5-8.

Тонкий верхний почвенный горизонт небольшой мощности - от 0,5 до $1 \mathrm{M}$, и характеризуется высокими значениями УЭС (45-150 Ом·м). Его геоэлектрические характеристики сильно изменяются по профилю без какой-либо общей тенденции, по-видимому, они определяются локальными геоморфологическими особенностями.

На участке с суффозионными проявлениями выполнена серия измерений ВЭЗ по профилям, совмещенным с измерениями 3С. Рассмотрим геоэлектрический разрез, построенный по субширотному профилю ПР 4, проходящему по линии размещения воронок $1-4,15$ (рис. 7).

На геоэлектрическом разрезе по профилю ПР 4 видно, что воронки 2-4 и 15 в приповерхностной части разреза подстилаются неоген-четвертичным отложениям с повышенными значениями УЭС до 15 Ом·м. В районе ПК 34-35 в неоген-четвертичных отложениях, на глубине 20 м, наблюдается протяженная низкоомная зона со значениями УЭС 4-10 0м·м, что согласуется с результатами $3 \mathrm{C}$ по этому же профилю. Ниже по разрезу выделяются отложения юрской и меловой систем с УЭС в интервале 3-7 Ом·м. Пунктирными стрелками показана траектория разгрузки сбросовых вод.

Применение метода ВЭЗ при исследовании обусловлено возможностью более детального расчленение верхней части разреза до глубин в первые де-

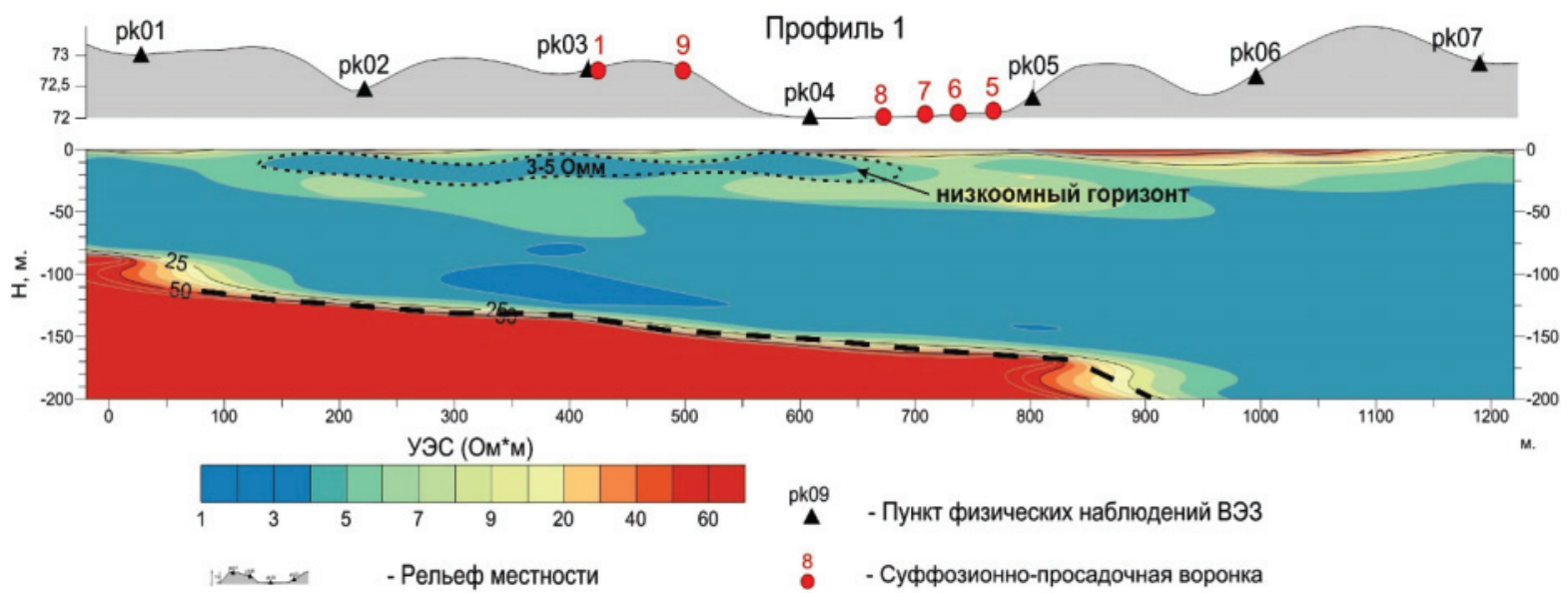

Puс. 6. Геоэлектрический разрез по профилю ПР1 по данныл вертикального электрического зондирования (ВЭЗ)

Fig. 6. Geoelectric section on the profile PR1 according to the vertical electric sounding (VES) data 


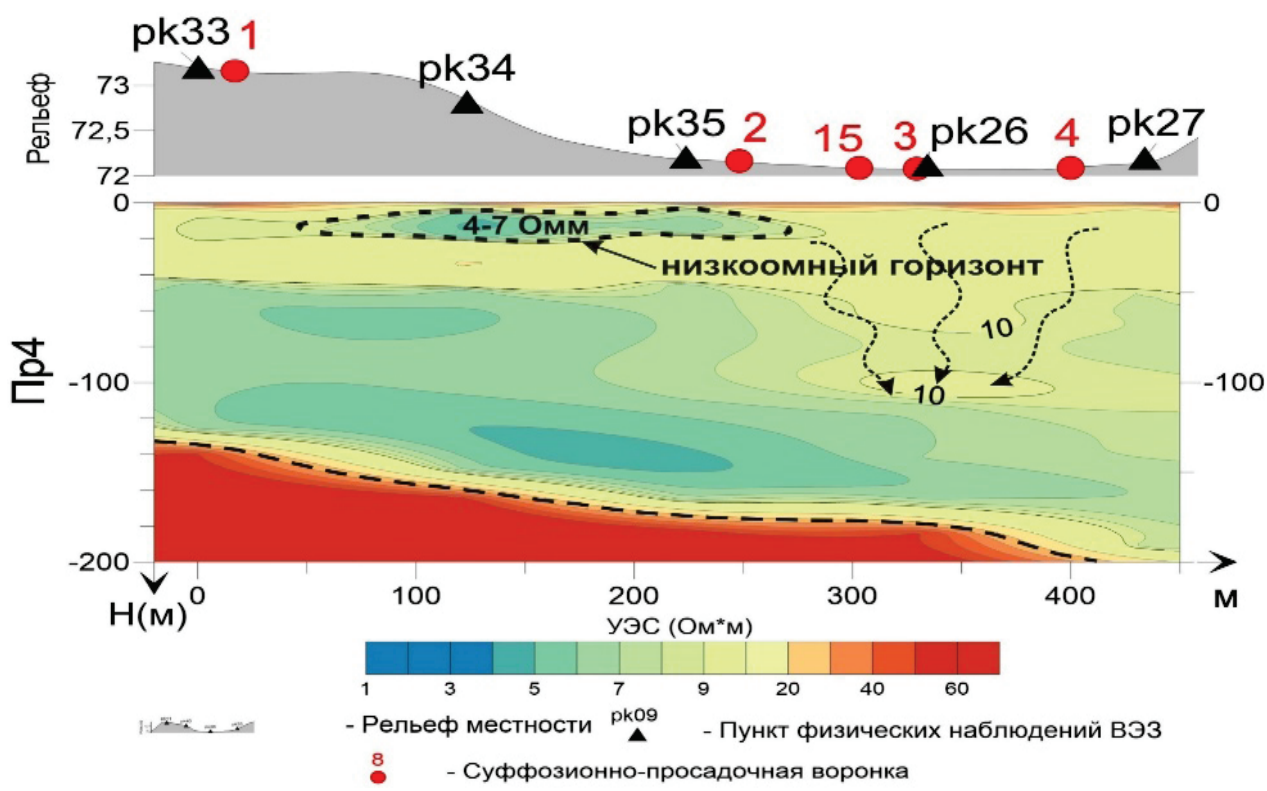

Рис. 7. Геоэлектрический разрез по профилю ПР 4 по данныл вертикального электрического зондирования (ВЭЗ)

Fig. 7. Geoelectric section on the profile PR4 according to the vertical electric sounding (VES) data

сятки метров для сопоставления и согласования с данными электротомографии. А в интервале глубин примерно от 50 до 100 м данные ВЭЗ и $3 \mathrm{C}$ хорошо согласуются, что повышает общую достоверность результатов. В целом по данным ВЭЗ уточнено строение приповерхностных отложений неогенчетвертичного возраста, выделены зоны наиболее низкого УЭС, вероятнее всего, обводненные.

Таким образом, по комплексу данных ВЭЗ и ЗС мощность отложений меловой и юрской систем изменяется от 40 м в западной части участка до 250-300 м в его восточной части, а УЭС - от 3 до 6 Ом·м. Геоэлектрические параметры триасовых и солянокупольных отложений, особенности их залегания определены по данным метода $3 \mathrm{C}$.

Интерпретаиия данных электротолографии. Обоснованием применения метода является его высокая эффективность при работах с целью определения геоэлектрических параметров деструктивных проявлений, таких как разломные нарушения, карстовые образования [18, 19].

Предварительная обработка полевых данных ЭТ в зоне воронок выполнена с помощью программного обеспечения SiBER Tools, предназначенного для создания и редактирования файлов с параметрами установок, а также первичной обработки данных, которая заключается в фильтрации, компоновке и экспорте данных в программы интерпретации. Для интерпретации данных и визуализации результатов использован программный пакет RES2D (компания Geotomo softwear, Малайзия) [20], ERTlab [21].

По данным электротомографии определено детальное геоэлектрическое строение приповерхностных неоген-четвертичных отложений до глубины 40 м. Полученный интервал значений УЭС от 1 до 30 Ом·м для этих отложений в принципе согласуется с данными ВЭЗ, а построенные разрезы наглядно отражают геоэлектрическое строение в зонах расположения суффозионных воронок.

Профиль 30 ЭТ проходит через воронку 2, а профиль 43 через воронку 14. На геоэлектрических разрезах по обоим профилям на глубине в 5-6 м непосредственно под воронкой выделяются отложения с повышенным значением УЭС относительно вмещающих пород $(8, \mathrm{~A}$, Б), что можно объяснить разуплотнением грунта.

Кроме того, одной из особенностей распределения воронок по площади является приуроченность большинства воронок к контакту протяженных высокоомных зон с более проводящими зонами, общим простиранием с запада на восток. Эти зоны выделены на глубинах, начиная от 15-20 м.

На основе результатов интерпретации площадных данных ЭТ построена трехмерная модель геоэлектрической среды до глубины 40 м (рис. 9). Изоповерхность на уровне 25 Ом·м оконтуривает выделенные высокомные зоны. Показано также размещение воронок (цветовая гамма отражает их объем).

\section{Обсуждение результатов на основе обобщенной геоэлектрической модели участка развития суффозионных процессов}

В результате анализа, обобщения и согласования геоэлектрических моделей, полученных по данным каждого метода геоэлектрики, была построена модель, характеризующая строение участка исследования в целом. От дневной поверхности до глубины 40 м модель построена по данным электротомографии, до глубины 120 м - по данным ВЭЗ, строение самых глубинных горизонтов до 500 м отражают данные 3 С. 
A

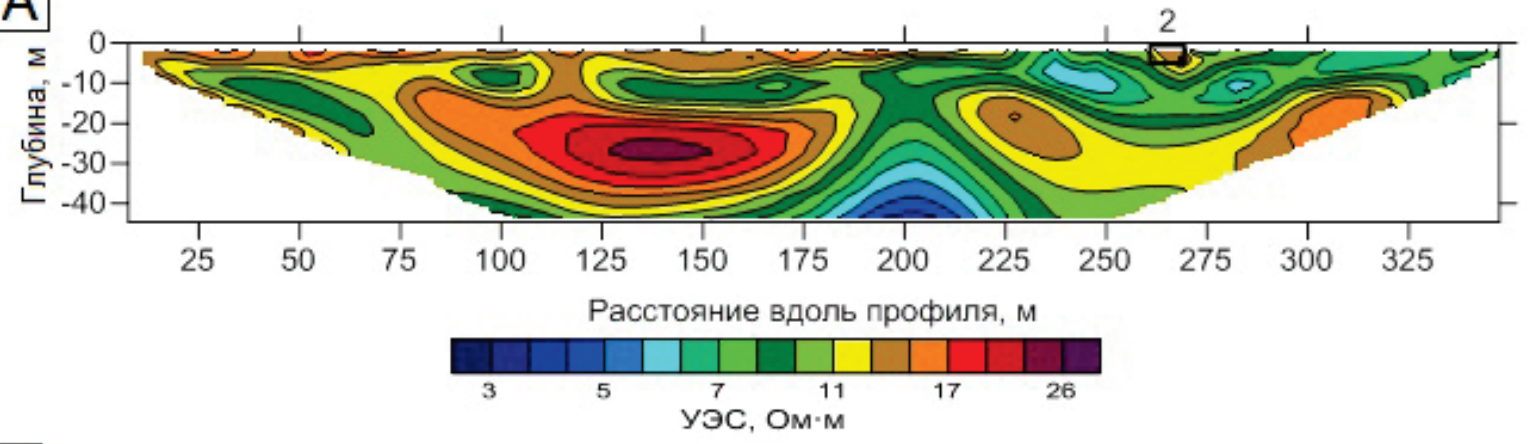

Б

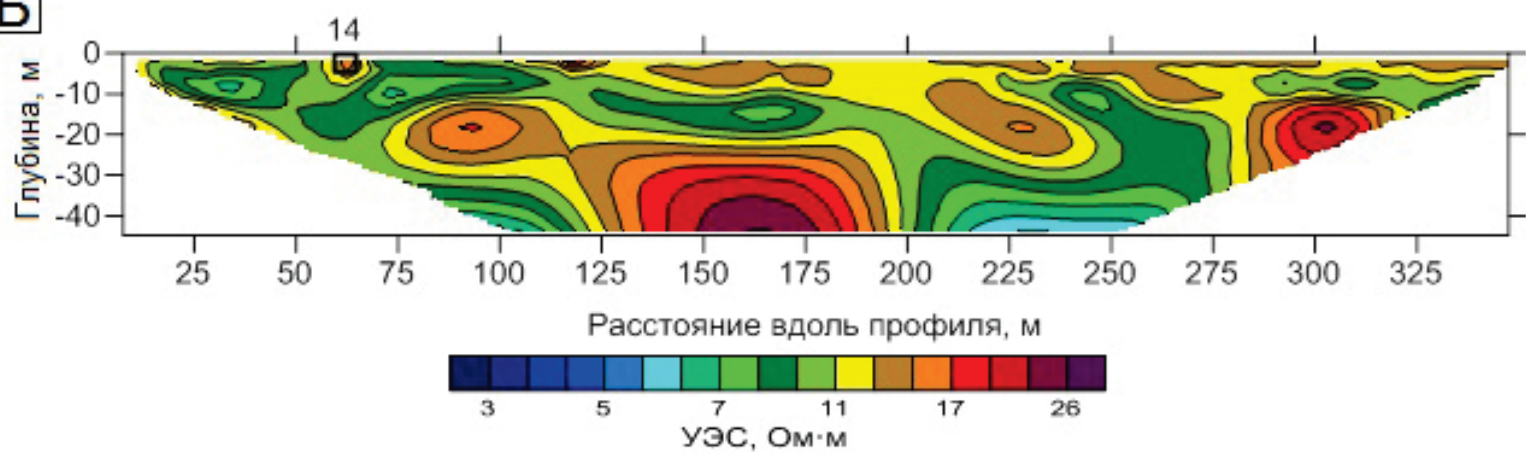

Puс. 8. Геоэлектрические разрезы по данным электротомографии по профилю: А) 30; Б) 43

Fig. 8. Geoelectric section according to electrotomography data on the profile: A) 30; Б) 43

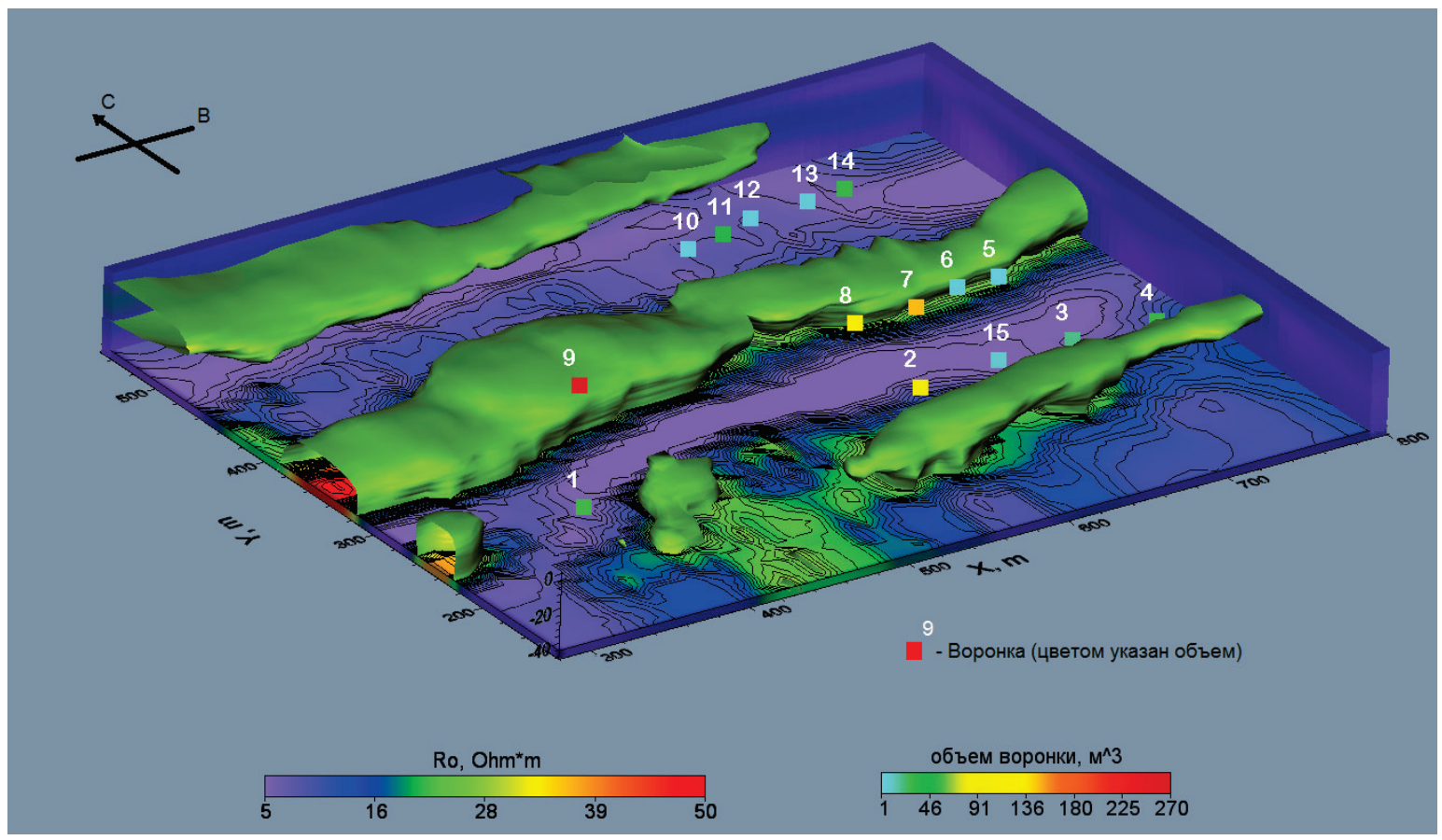

Pис. 9. Изоповерхность удельного электрического сопротивления на уровне 25 Ом.м по данным электротомографии

Fig. 9. Electrical resistivity isosurface at the level of $25 \mathrm{Om} \cdot \mathrm{m}$ according to electrotomography data 
В приповерхностной части геоэлектрической модели по данным ЭТ выделено чередование протяженных высокоомных и низкоомных зон, представленных отложениями неоген-четвертичного возраста и выделенных на глубинах от 15 до 40 м. Высокоомные зоны с УЭС от 25 до 50 Омм по геологическим данным могут быть соотнесены либо с более плотными малообводненными грунтами, либо с разуплотненными породами, из которых произошло вымывание глиняного и солевого «цемента». В свою очередь низкоомные зоны представлены более обводненными породами с УЭС 5-10 Омм. Суффозионные воронки 1, 10-14 находятся непосредственно в низкоомной зоне, а воронки 5-9, 2-4, 15 - на контакте высокоомных и низкоомных аномалий.

Аномально высокоомные протяженные отложения фактически являются ограничивающим фактором в развитии суффозионных процессов. С большой долей вероятности можно считать, что вдоль них и происходило вымывание растворимых отложений в глубину. Это привело к депрессии подповерхностного горизонта до глубин порядка 15-30 м с последующей просадкой грунтов. Поскольку по геологическим данным участок исследования расположен на границе надпойменной террасы и делювиального склона, чередование высокоомных и низкоомных зон, скорее всего, связано с особенностями формирования отложений на этой границе. Неоген-четвертичные слои верхней части разреза залегают с заметным несогласием на подстилающих горизонтах.
Далее на глубине от 40 до 80 м в западной части участка и от 40 до 200 м в его восточной части по данным ВЭЗ и ЗС выделяются ещё более низкоомные горизонты с уровнем УЭС от 3 до 6 Ом'м, соотнесённые с породами меловой и юрской систем. Они сложены породами глинистых и известняковых фракций с высоким уровнем минерализации подземных вод. По этим обводненным горизонтам как раз и происходила разгрузка сбросовых вод.

Ниже по разрезу по данным $3 \mathrm{C}$ и частично по данным ВЭЗ четко прослеживается тенденция погружения кровли горизонта с повышенным значением УЭС до 20-50 Омм, представленного по геологическим данным уплотненными породами глинистой фракции триасового возраста в интервале глубин до кровли от 80 м в западной части участка до 300 м в его восточной части. Мощность горизонта по разрезу постоянна и составляет $\sim 300 \mathrm{M}$. В процессе вымывания растворимых частиц в вышележащих слоях этот высокоомный горизонт являлся водоупорным, вдоль него происходил сток подземных вод вниз по склону.

В западной части участка в районе двух пунктов 3С ПК 1 и ПК 2, под высокоомными отложениями триаса, отмечено появление низкоомного интервала (УЭС 6-7 Ом·м) на глубинах 400-500 м, обусловленного наличием проводящих горных пород в кровле соленосного купола. По данным $3 \mathrm{C}$ в западной части, где кровля купола расположена ближе всего к дневной поверхности, удалось определить его геоэлектрические параметры. Согласно геологическим данным, погружение кровли соляного

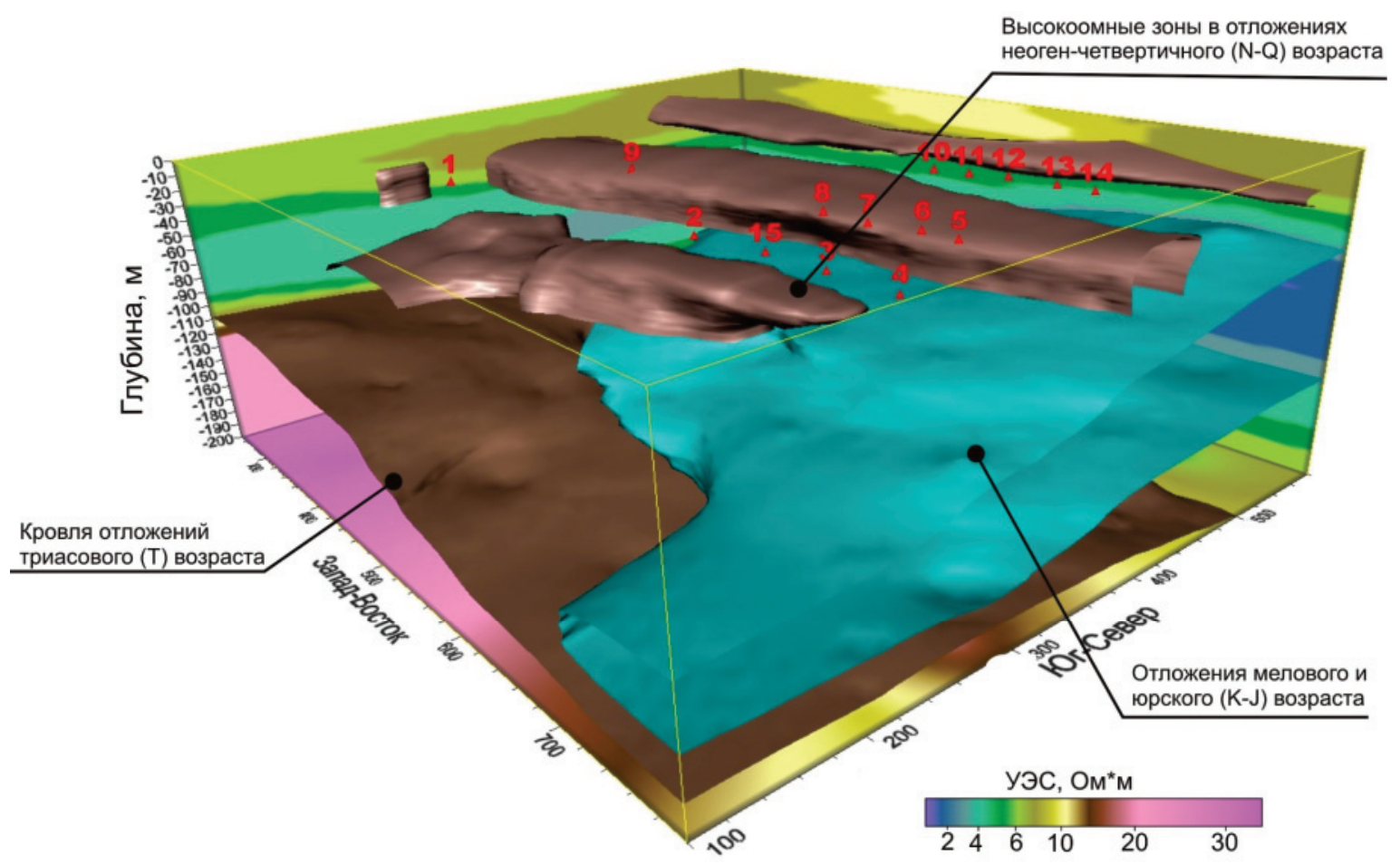

Рис. 10. Трехмерная визуализация геоэлектрического строения участка

Fig. 10. Three-dimensional visualization of the site geoelectric structure 
купола происходит на восток, что полностью подтверждено результатами интерпретации данных метода $3 \mathrm{C}$.

Выполнена трехмерная визуализация геоэлектрического строения основных структур участка, связанных с процессом развития суффозионнопросадочных процессов (рис. 10).

Известно, что одной из причин возникновения суффозионных процессов является искусственное нарушение режима подземного потока. Например, открытый водоотлив из котлованов часто вызывает такое увеличение скорости движения потока подземных вод, что он приводит к выносу частиц из грунта [22]. На участке исследования нарушение гидрогеологического режима связано с постройкой гидротехнического сооружений. В 1950-1960 гг. прошлого столетия в русле одной из балок было создано водохранилище, расположенное южнее участка проявления суффозионных явлений. В приплотинной зоне его левого борта выполнено водоотводное сооружение для сброса излишков воды из водохранилища по сухому логу в понижение, к которому и приурочено большинство суффозионных провалов. Таким образом, возникший новый поверхностный водоток вместе с участками разливов сбросовых вод в его устье, вероятнее всего, стал фактором интенсивного увлажнения суглинистых просадочных грунтов естественного сложения, а его продолжительное воздействие вызвало активизацию суффозионно-просадочного процесса.

Исходя из геоэлектрического строения, воронки на участке исследования можно разделить на две группы, и у каждой из групп предполагается свой механизм образования. Первая группа, в которую входит большинство воронок с номерами $2-8,10-15$, расположена в зоне пониженных значений абсолютных высотных отметок, соответствующих руслу сброса вод из водохранилища. Оcновной механизм их образования связан с разгрузкой сбросовых вод в подстилающие низкоомные горизонты меловой и юрской систем. Вклад инфильтрации атмосферных осадков и талых вод несущественен. При периодических сбросах из водохранилища вода вымывала из приповерхностных неоген-четвертичных отложений глиняный и солевой «цемент», а выявленные зоны высокоомных пород в этих отложения задавали направление вымывания. Затем воды фильтровались в подстилающие низкоомные горизонты меловой и юрской систем, и далее по склону уходили на глубину. Поэтому образование этих воронок происходило быстрее всего. Сейчас деструктивные процессы за счет вымывания солей практически закончены. Подстилающие породы, контролирующие данные воронки, скорей всего, имеют устойчивые геоэлектрические параметры.

Несколько другой механизм образования второй группы воронок -1 и 9 . Они находятся вне основного русла сброса вод, и основной вклад в вымывание цементирующих компонент грунтов верхней части разреза происходит именно за счет инфильтрации талых вод и атмосферных осадков в подстилающие низкоомные горизонты меловой и юрской систем. По результатам анализа геоэлектрических параметров среды участков с этими двумя воронками, можно с достаточной долей уверенности предположить, что процесс их формирования еще не закончен и, скорее всего, он будет более длительным. Визуальный осмотр воронок подтверждает этот вывод. У воронки 9 наблюдаются крутые края, не полностью сформировавшийся поверхностный покров. Для воронки 1 таких внешних факторов не отмечено, что, возможно, объясняется более медленной скоростью деструкции.

\section{Выводы}

На основе анализа полученных результатов выявлены главные причины образования и закономерности размещения суффозионных воронок на данном участке. Преобладание монтмориллонита в тонкодисперсной фракции в сочетании с засоленностью грунтов способствовало развитию процессов набухания и просадочных свойств. Ведущей техногенной причиной формирования провалов являлось образованное в русле одной из балок водохранилище, создавшее новый поверхностный водоток, интенсивно увлажнявший суглинистые просадочные грунты естественного сложения, а его продолжительное воздействие привело к активизации суффозионно-просадочного процесса. Разгрузка сбросовых вод происходила в подстилающие низкоомные (обводненные) горизонты меловой и юрской систем, а погружение водоупорных глинистых отложений триасового возраста с запада на восток определяло направление выноса растворенных частиц в более глубинные горизонты. Линейность размещения воронок, совпадающая с простиранием выявленных чередующихся протяженных низкоомных и высокоомных зон подповерхностных отложений, связана, по геологическим данным, с особенностями формирования неоген-четвертичных отложений на границе третьей надпойменной террасы, протекающей здесь реки и делювиального склона.

\section{Заключение}

По результатам выполненного исследования определено приповерхностное и глубинное геоэлектрическое строение участка проявления суффозионно-просадочных процессов, выявлены закономерности расположения суффозионных воронок относительно подстилающих отложений, и предложена модель процесса их формирования. По данным геоэлектрики сделан вывод, что основной механизм образования воронок связан с вымыванием известнякового и солевого "цемента» из неоген-четвертичных отложений и дальнейшей разгрузкой сбросовых вод в подстилающие низкоомные горизонты меловой и юрской систем. Далее вдоль кровли триаса, вниз по склону, эти воды уходят в глубину массива горных пород. 


\section{СПИСОК ЛИТЕРАТУРЫ}

1. Аникеев А.В. Суффозия. Механизм и кинематика свободной суффозии // Геоэкология. - 2006. - № 6. - С. 544-553.

2. Аникеев А.В., Леоненко М.В. Прогноз провалообразования при изменении гидродинамического режима на примере Дзержинского карстового района // Геоэкология. Инженерная геология. Гидрогеология. Геокриология. - 2013. - № 2. C. $130-146$.

3. Akhmedenov K.M., Iskaliev D.Zh., Petrishev V.P. Karst and Pseudokarst of the West Kazakhstan (Republic of Kazakhstan) // International Journal of Geosciences. - 2014. - № 5. P. 131-136.

4. Loke M.H., Barker R.D. Rapid least-squares inversion of apparent resistivity pseudosections by a quasi-Newton method // Geophysical Prospecting. - 1996. - № 44 (1). - P. 131-152.

5. Паршаков Е.И. Исследования закарстованности участка методов ВЭЗ // Стратегия и процессы освоения георесурсов: сб. науч. труд. Вып. № 14. - Пермь: ГИ Ур0 РАН, 2016. C. $234-235$.

6. Kamenetsky F.M. Trigubovich G.M., Chernyshev A.V. The geological medium induced polarization as an electromagnetic phenomenon // Extended Abstracts. 22 $2^{\text {nd }}$ EM Induction Workshop. Weimar, Germany, August 24-30, 2014. - P. 4.

7. Displacement currents in geoelectromagnetic problems / V. Mogilatov, M. Goldman, M. Persova, Y. Soloveichik // Journal of Applied Geophysics. - 2014. - V. 105. - P. 133-137.

8. Чубаров М.В., Власов А.А., Шалагинов А.Е. Построение трехмерных геоэлектрических моделей для метода зондирования становлением поля в ближней зоне на основе результатов одномерной инверсии // Недропользование. Горное дело. Новые направления и технологии поиска, разведки и разработки месторождений полезных ископаемых. Геоэкология: ИНТЕРЭКСПО ГЕ0-Сибирь-2017. XIII междунар. науч. конгр. - Новосибирск, 17-21 апреля 2017. - Т. 4. - С. 129-134.

9. Бабушкин С.М., Неведрова Н.Н. Аппаратурные и методические средства при поисках рудных месторождений методом нестационарного электромагнитного зондирования // Недропользование. Горное дело. Новые направления и технологии поиска, разведки и разработки месторождений полезных ископаемых. Геоэкология: ИНТЕРЭКСПО ГЕО-Сибирь-2017. ХІІІ междунар. науч. конгр. - Новосибирск, 17-21 апреля 2017. T. 2. - C. 271-275.

10. Kaufman A.A., Oristaglio M., Alekseev D. Principles of Electromagnetic Methods in Surface Geophysics. - Amsterdam: Elsevier, 2014. $-794 \mathrm{p}$.

11. 0 комплексировании методов ВЭЗ и ЗС в ближней зоне / П.В. Иванов, Д.А. Алексеев, А.П. Бобачев, П.Ю. Пушкарев,
А.Г. Яковлев // Инженерные изыскания. - 2011. - № 11. C. $42-51$.

12. Новый подход к малоглубинным электромагнитным зондированиям / Е.В. Балков, Д.И. Фадеев, Ю.Г. Карин, А.К. Манштейн, Ю.А. Манштейн, Г.Л. Панин // Геология и геофизика. - 2017. - T. 58. - № 5. - С. 783-791.

13. Perrone A., Lapenna V., Piscitelli S. Electrical resistivity tomography technique for landslide investigation: a review // EarthScience reviews. - 2014. - № 135. - P. 65-82.

14. Ability of high-resolution resistivity tomography to detect fault and fracture zones: application to the Tournemire experimental platform, France / C. Gelis, M. Noble, J. Cabrera, S. Penz, H. Chauris, E.M. Cushing // Pure and Applied Geophysics. 2016. - № 173. - P. 573-589.

15. Система интерпретации данных зондирований методом переходных процессов EMS / О.Г. Хабинов, И.А. Чалов, А.А. Власов, Е.Ю. Антонов // ГЕО-Сибирь-2009: Сборник материалов V Международного научного конгресса. - Новосибирск, 2009. C.108-113.

16. Каминский A.E. Программа ZondTEM1D. URL: http://zondgeo.ru (дата обращения 20.05.2018).

17. Результаты поисково-разведочных работ на полиметаллы методами электроразведки с контроллируемыми источниками в районе Рудного Алтая / С.М. Бабушкин, А.Н. Егоров, Н.Н. Неведрова, И.О. Шапаренко // Известия Томского политехнического университета. Инжиниринг георесурсов. - 2017. T. 328. - № 11. - C. 97-110.

18. Шапаренко И.О., Неведрова Н.Н. Мониторинг разломных зон методом электротомографии (на примере Горного Алтая) // Проблемы геодинамики и геоэкологии внутриконтинентальных орогенов: Тезисы докладов VII Международного симпозиума. - Бишкек, 19-24 июня 2017. - С. 433-437.

19. Geoelectrical resistivity variations and lithological composition in coastal gypsum rocks: A case study from the Lesina Marina area (Apulia, southern Italy) / V. Festa, S. Tripaldi, A. Siniscalchi, P. Acquafredda, A. Fiore, D. Mele, G. Romano // Engineering Geology. - 2016. - № 202. - P. 163-175.

20. Loke M.H. Resistivity and IP imaging // Geotomo Software Pty Ltd. - 2015. URL: http://www.geotomosoft.com (дата обращения 20.05.2018).

21. Morelli G., LaBrecque D.J. Advances in ERT inverse modelling // European Journal of Environmental and Engineering Geophysics. - 1996. - № 1. - P. 171-186.

22. Гришин М.М. Гидротехнические сооружения. - М.: Энергия, 1968. $-344 \mathrm{c}$.

Поступила 23.05.2018 2.

\section{Информация об авторах}

Шалагинов A.E., кандидат геолого-минералогических наук, старший научный сотрудник Института нефтегазовой геологии и геофизики им. А.А. Трофимука СО РАН; доцент Физико-технического факультета Новосибирского государственного технического университета.

Неведрова H.H., доктор геолого-минералогических наук, ведущий научный сотрудник Института нефтегазовой геологии и геофизики им. А.А. Трофимука СО РАН; доцент Геолого-геофизического факультета Новосибирского государственного университета.

Шапаренко И.О., младший научный сотрудник Института нефтегазовой геологии и геофизики им. А.А. Трофимука СО РАН.

Бабушкин С.M., заместитель директора Сейсмологического филиала Федерального исследовательского центра «Единая геофизическая служба» РАН. 


\title{
APPLICATION OF METHODS OF ELECTRICAL EXPLORATION WITH CONTROLLED SOURCES FOR DETECTING CAUSES OF SUB-PASS-LOCATION PROCESSES DEVELOPMENT
}

\author{
Aleksandr E. Shalaginov ${ }^{1,2}$, \\ shalaginovae@ipgg.sbras.ru \\ Nina N. Nevedrova ${ }^{1,3}$, \\ nevedrovann@ipgg.sbras.ru
}

llya 0. Shaparenko', shaparenkoio@ipgg.sbras.ru

\section{Sergey M. Babushkin ${ }^{4}$,} bab@gs.sbras.ru

\author{
'Institute of Petroleum Geology and Geophysics of Siberian Branch of Russian Academy of Sciences, \\ 3, Academician Koptyug avenue, Novosibirsk, 630090, Russia. \\ ${ }^{2}$ Novosibirsk State Technical University, \\ 20, K. Marksa avenue, Novosibirsk, 630073, Russia \\ ${ }^{3}$ Novosibirsk State University, \\ 1, Pirogov street, Novosibirsk, 630090, Russia. \\ ${ }^{4}$ Seismological Branch of Federal Research Center «Russian Academy of Sciences Geophysical Survey», \\ 3, Academician Koptyug avenue, Novosibirsk, 630090, Russia.
}

The relevance of the work is caused by insufficiency of knowledge on the reasons of development of suffusion processes expressed as land surface failures menacing to infrastructure of industrial production in Caspian Depression.

The aim of the research is to determine the near-surface and deep geoelectric structure of the site of manifestations of suffusion-subsidence formations to identify possible causes of their occurrence.

Object of the research are suffusion-subsidence formations in the form of funnel-shaped earth surface dips with a depth of 1 to $6 \mathrm{~m}$ in an amount of 15 pieces located in three practically parallel zones.

Methods. The entire volume of field data is obtained by three different depth methods of geoelectrics: electrotomography, vertical electric sounding, non-stationary electromagnetic sounding. Processing, interpretation, visualization of data were carried out using interactive simulation and inversion software packages ERA, EMS, Zond, Res2D, ERTLab. The justification of the results is based on the analysis and comparison of the obtained geoelectric data with a priori geological data.

Results. Based on the results of the work done, with depths of up to 400-500 m, sections and maps of electrical resistivity distribution at different depths, three-dimensional geoelectric models for both the near-surface and the deep part of the section were constructed. As a result of geological interpretation of the data, the zones were identified (according to the resistivity parameter) to which the existing funnels were confined, the direction of removal of the destroyed (washed out) rocks was determined. The authors identified the structures related to the zones of development of suffusion-subsidence processes, and stated possible reasons for their formation. Conclusions. The paper demonstrates high efficiency of the complex of electromagnetic methods used on the site with the destructive phenomena. It is concluded that the main mechanism for funnels formation is associated with leaching of limestone and salt "cement» from the N-Q sediments, with further unloading into deeper watered horizons. This complex can be recommended at the solution of similar tasks in other regions where there are zones of manifestation of suffusion processes, and also for monitoring their development.

\section{Key words:}

Geoelectric structure, vertical electric sounding, electrotomography, non-stationary electromagnetic sounding, suffosion processes.

\section{REFERENCES}

1. Anikeev A.V. Suffoziya. Mekhanizm i kinematika svobodnoy suffozii [Mechanism and kinematics of free suffusion]. Geoekologi$y a, 2006$, no. 6 , pp. 544-553.

2. Anikeev A.V., Leonenko M.V. Prognoz provaloobrazovaniya pri izmenenii gidrodinamicheskogo rezhima na primere Dzerzhinskogo karstovogo rayona [Prediction of failure formation at changes of hydrodynamic regime on the example of the Dzerzhinsky karst region]. Geoekologiya. Inzhenernaya geologiya. Gidrogeologiya. Geokriologiya, 2013, no. 2, pp. 130-146.

3. Akhmedenov K. M., Iskaliev D. Zh., Petrishev V. P. Karst and Pseudokarst of the West Kazakhstan (Republic of Kazakhstan). International Journal of Geosciences, 2014, no. 5, pp. 131-136.
4. Loke M.H., Barker R.D. Rapid least-squares inversion of apparent resistivity pseudosections by a quasi-Newton method. Geophysical Prospecting, 1996, no. 44 (1), pp. 131-152.

5. Parshakov E.I. Issledovaniya zakarstovannosti uchastka metodov VEZ [Studies of karsts of the site by the VES methods]. Strategiya i protsessy osvoeniya georesursov: sbornik nauchnykh trudov [Strategy and processes of georesources development: Sat. scientific work]. Perm, GI Ur0 RAN Publ., 2016. No. 14, pp. 234-235.

6. Kamenetsky F.M., Trigubovich G.M., Chernyshev A.V. The geological medium induced polarization as an electromagnetic phenomenon. Extended Abstracts, $22^{\text {nd }}$ EM Induction Workshop. Weimar, Germany, August 24-30, 2014. pp. 4. 
7. Mogilatov V., Goldman M., Persova M., Soloveichik Y. Displacement currents in geoelectromagnetic problems. Journal of Applied Geophysics, 2014, vol. 105, pp. 133-137.

8. Chubarov M.V., Vlasov A.A., Shalaginov A.E. Postroenie trekhmernykh geoelektricheskikh modeley dlya metoda zondirovaniya stanovleniem polya $\mathrm{v}$ blizhney zone na osnove rezultatov odnomernoy inversii [Construction of three-dimensional geoelectric models for the TEM method based on the results of one-dimensional inversion]. Nedropolzovanie. Gornoe delo. Novye napravleniya i tekhnologii poiska, razvedki i razrabotki mestorozhdeny poleznykh iskopaemykh. Geoekologiya. Materialy XIII mezhdunarodnoy nauchnoy konferentsii [Subsoil use. Mining. New directions and technologies for prospecting, exploration and development of mineral deposits. Geoecology. Materials of the $13^{\text {th }}$ International Scientific Conference]. Novosibirsk, 2017. Vol. 4, pp. 129-134.

9. Babushkin S.M., Nevedrova N.N. Apparaturnye i metodicheskie sredstva pri poiskakh rudnykh mestorozhdeny metodom nestatsionarnogo elektromagnitnogo zondirovaniya [Instrumental and methodical means in the search for ore deposits by the method of nonstationary electromagnetic sensing]. Nedropolzovanie. Gornoe delo. Novye napravleniya i tekhnologii poiska, razvedki i razrabotki mestorozhdeny poleznykh iskopaemykh. Geoekologiya. Materialy XIII mezhdunarodnoy nauchnoy konferentsii [Subsoil use. Mining. New directions and technologies for prospecting, exploration and development of mineral deposits. Geoecology. Materials of the $13^{\text {th }}$ International Scientific Conference]. Novosibirsk, 2017. Vol. 2, pp. 271-275.

10. Kaufman A.A., Oristaglio M., Alekseev D. Principles of Electromagnetic Methods in Surface Geophysics. Amsterdam, Elsevier, $2014.794 \mathrm{p}$.

11. Ivanov P.V., Alekseev D.A., Bobachev A.P., Pushkarev P.Yu., Yakovlev A.G. On integrated application of the VES and TEM geophysical methods. Inzhenernye izyskaniya, 2011, no. 11, pp. 42-51. In Rus.

12. Balkov E.V., Fadeev D.I., Karin Yu.G., Manshteyn A.K., Manshteyn Yu.A., Panin G.L. A new approach to shallow-depth electromagnetic sounding. Russian Geology and Geophysics, 2017, vol. 58, no. 5, pp. 783-791. In Rus.

13. Perrone A., Lapenna V., Piscitelli S. Electrical resistivity tomography technique for landslide investigation: a review. Earth-Science reviews, 2014, no. 135, pp. 65-82.
14. Gelis C., Noble M., Cabrera J., Penz S., Chauris H., Cushing E.M. Ability of high-resolution resistivity tomography to detect fault and fracture zones: application to the Tournemire experimental platform, France. Pure and Applied Geophysics, 2016, no. 173, pp. $573-589$.

15. Khabinov 0.G., Chalov I.A., Vlasov A.A., Antonov E.Yu. Sistema interpretatsii dannykh zondirovaniya metodom perekhodnykh protsessov EMS [System for interpretation of transient electromagnetic sounding data EMS]. GEO-Sibir-2009: Sbornik materialov V Mezhdunarodnogo nauchnogo kongressa [Geo-Sibir. Materials of the $\mathrm{V}^{\text {th }}$ International scientific congress]. Novosibirsk, 2009. pp. 108-113.

16. Kaminsky A.E. Programma ZondTEM1D [ZondTEM1D]. Available at: http://zond-geo.ru (accessed 20 May 2018).

17. Babushkin S.M., Egorov A.N., Nevedrova N.N., Shaparenko I.0. Results of exploration for polymetals by electrical survey methods with controlled sources in the Rudny Altai region. Bulletin of the Tomsk Polytechnic University. Geo assets Engineering, 2017, vol. 328 , no. 11, pp. 97-110. In Rus.

18. Shaparenko I.0., Nevedrova N.N. Monitoring razlomnykh zon metodom elektrotomografii (na primere Gornogo Altaya) [Monitoring of fault zones by electro-tomography (the example of Gorny Altai)]. Problemy geodinamiki i geoekologii unutrikontinentalnykh orogenov. Tezisy dokladov VII Mezhdunarodnogo simpoziu$\mathrm{ma}$ [Problems of geodynamics and geoecology of intracontinental orogens. Abstracts of the VII International Symposium]. Bishkek, 2017. pp. 433-437.

19. Festa V., Tripaldi S., Siniscalchi A., Acquafredda P., Fiore A., Mele D., Romano G. Geoelectrical resistivity variations and lithological composition in coastal gypsum rocks: A case study from the Lesina Marina area (Apulia, southern Italy). Engineering Geology, 2016, no. 202, pp. 163-175.

20. Loke M.H. Resistivity and IP imaging. Geotomo Software Pty Ltd. 2015. Available at: http://www.geotomosoft.com (accessed 20 May 2018).

21. Morelli G., LaBrecque D.J. Advances in ERT inverse modelling. European Journal of Environmental and Engineering Geophysics, 1996, vol. 1, no. 2, pp. 171-186.

22. Grishin M.M. Gidrotekhnicheskie sooruzheniya [Hydrotechnical structures]. Moscow, Energiya Publ., 1968. 344 p.

Received: 23 May 2018.

\section{Information about the authors}

Aleksandr E. Shalaginov, Cand. Sc., senior researcher, Institute of Petroleum Geology and Geophysics of Siberian Branch of Russian Academy of Sciences; assistant professor, Novosibirsk State Technical University.

Nina N. Nevedrova, Dr. Sc., leading researcher, Institute of Petroleum Geology and Geophysics of Siberian Branch of Russian Academy of Sciences; assistant professor, Novosibirsk State University.

Ilya O. Shaparenko, junior researcher, Institute of Petroleum Geology and Geophysics of Siberian Branch of Russian Academy of Sciences.

Sergey M. Babushkin, deputy director, Seismological Branch of Federal Research Center «Russian Academy of Sciences Geophysical Survey». 